\title{
National and public security within and beyond the Police Directive
}

Plixavra Vogiatzoglou* and Stefano Fantin*

[Preprint of Vogiatzoglou, P. and Fantin, S. 'National and public security within and beyond the Police Directive'. In: Anton Vedder, Jessica Schroers, Charlotte Ducuing \& Peggy Valcke (eds), Security and Law. Legal and Ethical Aspects of Public Security, Cyber Security and Critical Infrastructure Security. Cambridge, Antwerp, Chicago: Intersentia, 2019, pp. 27-62]

\section{Table of Contents}

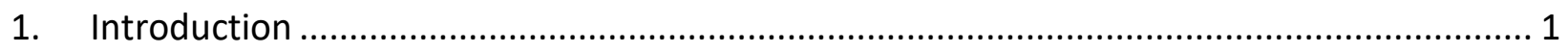

2. The scope of the Data Protection Law Enforcement Directive ..................................... 3

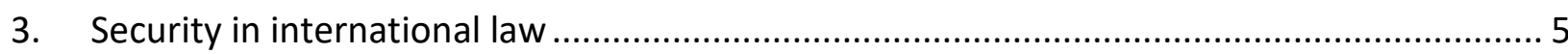

3.1. Theoretical bases from philosophy of law ........................................................ 6

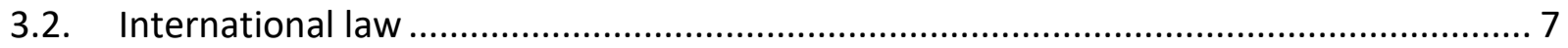

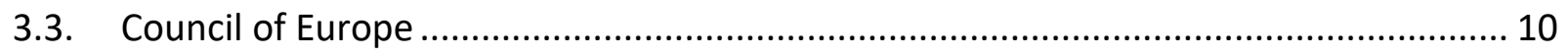

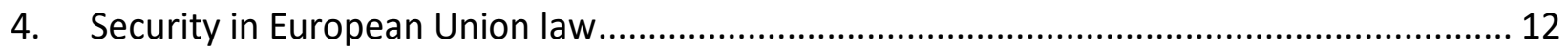

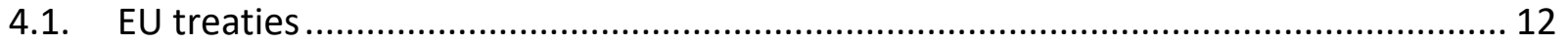

4.2. Jurisprudence on security as derogation ........................................................... 14

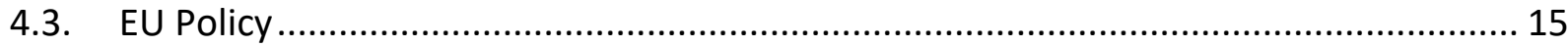

4.4. Security and personal data in secondary EU law .................................................. 16

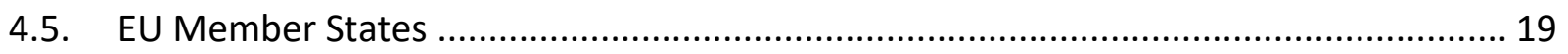

5. Competent authorities under the DPLE Directive .................................................. 20

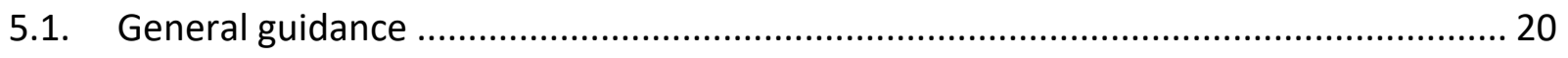

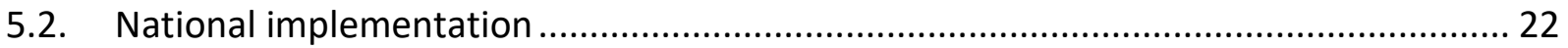

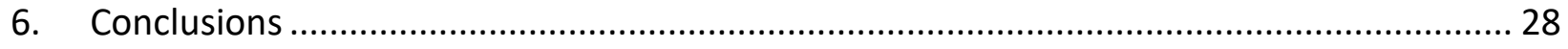

\section{Introduction}

\footnotetext{
* The authors contributed equally to this work. For correspondence please refer to plixavra.vogiatzoglou@kuleuven.be or stefano.fantin@kuleuven.be.
} 
The Directive (EU) 2016/680, also referred to as the Data Protection Law Enforcement Directive, (hereinafter the DPLE Directive) ${ }^{1}$ that accompanies the General Data Protection Regulation (hereinafter the GDPR $)^{2}$ is often left to one side in most discussions around the EU Data Protection Reform of 2016 (also including the Passenger Name Records - hereinafter PNR - Directive ${ }^{3}$ ). On its own merit, the DPLE Directive was praised for broadening the scope of data protection in the criminal justice sector, from the previous cross-border regime (Council Framework Decision 2008/977/JHA, hereinafter the Framework Decision ${ }^{4}$ ) to a much wider territorial remit, extending its rules to purely internal data processing. During its drafting, however, the major European data protection supervisory bodies, i.e. the European Data Protection Supervisor (hereinafter EDPS), and the Article 29 Working Party (currently European Data Protection Board, hereinafter WP29), raised their concerns with regards to the scope of the directive, in particular the purpose of safeguarding public security. As the directive applies to the processing of personal data by competent authorities for the purposes of the prevention, investigation, detection or prosecution of criminal offences including the safeguarding against and the prevention of threats to public security, the EDPS ${ }^{5}$ and $\mathrm{WP}^{2} \mathrm{9}^{6}$, in their respective Opinions on the Proposal for the DPLE Directive, objected to the inclusion of this last phrase, pointing out the potential for legal uncertainty that such wording may lead to. More specifically, the directive does not further define the notion of public security, while explicitly juxtaposing the concept to national security, as the latter is excluded from the scope of application of the legislation.

At the time of writing, nineteen Member States have been notified by the European Commission of an infringement procedure against them, due to their delay in implementing the Directive throughout their respective national processes. ${ }^{7}$ Several months after the official deadline for the national transposition of

\footnotetext{
${ }^{1}$ Directive (EU) 2016/680 of the European Parliament and of the Council of 27 April 2016 on the protection of natural persons with regard to the processing of personal data by competent authorities for the purposes of the prevention, investigation, detection or prosecution of criminal offences or the execution of criminal penalties, and on the free movement of such data, and repealing Council Framework Decision 2008/977/JHA [2016] OJ L 119, 89 (Directive (EU) 2016/680).

${ }^{2}$ Regulation (EU) 2016/679 of the European Parliament and of the Council of 27 April 2016 on the protection of natural persons with regard to the processing of personal data and on the free movement of such data, and repealing Directive 95/46/EC (General Data Protection Regulation) (Text with EEA relevance), OJ L 119, 4.5.2016, 1 (Regulation (EU) 2016/679)

${ }^{3}$ Directive (EU) 2016/681 of the European Parliament and of the Council of 27 April 2016 on the use of passenger name record (PNR) data for the prevention, detection, investigation and prosecution of terrorist offences and serious crime, OJ L 119, 132.

${ }^{4}$ Council Framework Decision 2008/977/JHA of 27 November 2008 on the protection of personal data processed in the framework of police and judicial cooperation in criminal matters, [2008] OJ L 350, 60.

${ }^{5}$ European Data Protection Supervisor, Opinion 6/2015, 28 October 2015, p. 6.

${ }^{6}$ Article 29 Data Protection Working Party, Opinion 03/2015 on the draft directive on the protection of individuals with regard to the processing of personal data by competent authorities for the purposes of prevention, investigation, detection or prosecution of criminal offences or the execution of criminal penalties, and the free movement of such data, WP233, 01 December 2015.

${ }^{7}$ European Commission, Seventeenth Progress Report towards an Effective and Genuine Security Union (2018)
} 
the directive, the interpretative questions highlighted above have not been given any more thought by both regulators and scholarly literature. ${ }^{8}$

Against this backdrop, this chapter aims at triggering further reflections about the Data Protection Law Enforcement Directive in a number of communities, first and foremost Member States' legislators, data protection regulators and academics. Specifically, it will do so by seeking to clarify the scope of the directive and the meaning of public security within, by adopting a three-layered approach; first through its contraposition with the concept of national security, second through its operationalisation and third through the definition of competent authorities, as formulated in the text of the directive. With regard to the first of the above-mentioned objectives, this chapter will, by following a reductio ad absurdum approach, examine general theories and international law so as to identify the main elements that define national security in such domains. In order to achieve the second objective, public security within European Union primary and secondary law will be analysed. Lastly, as far as the third objective is concerned, the focus will shift to the concept of competent authorities within the meaning of the directive. For this notion to be clarified, examples from national laws transposing the directive will be considered.

\section{The scope of the Data Protection Law Enforcement Directive}

The DPLE Directive concerns the protection of natural persons with regard to the processing of personal data by competent authorities for the purposes of the prevention, investigation, detection or prosecution of criminal offences or the execution of criminal penalties. It has replaced the previous regime of the Framework Decision, as it entered into force on 5 May 2016 and was due to be transposed by the Member States by 6 May 2018. ${ }^{9}$ While the GDPR regulates the processing of personal data in general context, the processing of personal data within the law enforcement and criminal justice sectors has been considered to require a separate legal instrument, due to the special nature of security-related data and activities. ${ }^{10}$

The scope of the DPLE Directive is significantly broadened in comparison to the previous regime, set out by the Framework Decision, which was limited to the processing of personal data transmitted or made available between the Member States and thus only to cross-border transfers of data. On the contrary, the DPLE Directive now also includes the purely domestic processing of personal data by competent authorities. What further differentiates the latter legal instrument is that it does no longer find its legal basis in the Area of Freedom, Security and Justice and the EU competence on police and judicial

\footnotetext{
${ }^{8}$ Thomas Marquenie 'The Police and Criminal Justice Authorities Directive: Data protection standards and impact on the legal framework' (2017) Computer Law \& Security Review, 33:3, 324; Paul De Hert and Vagelis Papakonstantinou, 'The Police and Criminal Justice Data Protection Directive: Comment and Analysis' (2012) New Journal of European Criminal Law, 7(1), 7; Teresa Quintel, 'European Union - Article 29 Data Protection Working Party Opinion on the Law Enforcement Directive' (2018) 4 European Data Protection Law Review 104.; Franziska Boehm, 'Data Processing and Law Enforcement Access to Information Systems at EU Level' (2012) 36 Datenschutz und Datensicherheit - DuD 339.

${ }^{9}$ Directive (EU) 2016/680, art 63 and 64.

${ }^{10}$ Paul De Hert and Vagelis Papakonstantinou (n 8), p. 1-2.
} 
cooperation in criminal matters. In contrast, it is based on the Lisbon-introduced article 16 TFEU, which provided for the legal basis to regulate comprehensively all rules on data protection at large. ${ }^{11}$

Delving deeper into the body of the directive and the defining contour of its scope, the two key concepts delineating the application of the Directive are, on the one hand, the purpose of the processing and on the other hand the notion of 'competent authorities'. More specifically, the DPLE Directive applies to the "processing of personal data by competent authorities for the purposes of the prevention, investigation, detection or prosecution of criminal offences or the execution of criminal penalties, including the safeguarding against and the prevention of threats to public security" [emphasis added by authors]. ${ }^{12}$ Furthermore, a competent authority is defined as either "any public authority competent for the prevention, investigation, detection or prosecution of criminal offences or the execution of criminal penalties, including the safeguarding against and the prevention of threats to public security" or "any other body or entity entrusted by Member State law to exercise public authority and public powers" for the same abovementioned purposes. ${ }^{13}$ It is also important to note that neither the DPLE Directive nor the GDPR apply to the processing of personal data in the course of an activity which falls outside the scope of Union Law (i.e. beyond the competences afforded to the EU by the Member States). ${ }^{14}$ While the text of the initial proposal referred to national security explicitly within this provision, ${ }^{15}$ the reference was eventually moved to the recitals of the DPLE Directive. In particular, recital 14 sheds light on what constitutes activities that fall outside the scope of Union Law, by referring to examples such as activities concerning national security and activities falling within the scope of Chapter 2 of Title $V$ of the Treaty on European Union (TEU), that is the common foreign and security policy. ${ }^{16}$

Despite there being three separate and cumulative conditions, they seem to be intertwined in the sense that they all depend, in one way or another, on the notion of security, whether public or national. Furthermore, the competence of the authorities that are subject to the DPLE Directive is defined through the purposes, 'including the safeguarding of public security', and the entities' power to pursue those purposes, while activities concerning national security are excluded. It is thus safe to assume that the core concept on which the scope of the DPLE Directive depends is security and in particular public security. Therefore, in order to fully comprehend the scope of the directive and appraise its potential applicability in a context outside the strict realm of criminal justice, these three conditions (national security, purpose of public security and competent authority) must be further interpreted and clarified.

While the notion of public security is opposed to the notion of national security within the scope of the DPLE Directive, the latter does not provide for further definitions or analysis. It is not as clear, however,

\footnotetext{
${ }^{11}$ Marquenie (n 8).

12 Directive (EU) 2016/680, art 1(1).

${ }^{13}$ Directive (EU) 2016/680, art 3(7).

14 Directive (EU) 2016/680, art 2(3)(a), Regulation (EU) 2016/679, art 2(2)(a).

${ }^{15}$ Proposal for a Directive of the European Parliament and of the Council on the protection of individuals with regard to the processing of personal data by competent authorities for the purposes of prevention, investigation, detection or prosecution of criminal offences or the execution of criminal penalties, and the free movement of such data, $\operatorname{COM}(2012) 10$ final.

${ }^{16}$ Directive (EU) 2016/680, rec. 14. Similarly, Regulation (EU) 2016/679, rec. 16.
} 
what these notions entail, as they depend on international and European law as well as on the national policy of each Member State and their different understandings. ${ }^{17}$ Due to this lack of clarity, the major EU data protection authorities, i.e. the EDPS and the WP29, provided their opinion against the inclusion of the phrase 'including the safeguarding against and the prevention of threats to public security' in the determination of the scope of the Directive.

In particular, even though the observations by the EDPS in Opinion 6/2015 where made when the DPLE Directive was still in its drafting phase, many of the objections therein are still valid. ${ }^{18}$ With respect to the scope of this chapter, three considerations were made explicit. Firstly, that the unclarity of the term 'public security' leads to the extension of the application of the Directive to those police activities which are not strictly related to a criminal offence that has happened or is taking place. This is the case, for instance, with the protection of public order, where extensive surveillance measures like videomonitoring are often applied in the context of rallies, demonstrations or sports events. Secondly, that the term 'competent authority' should be interpreted narrowly, thus keeping out of the scope of application of the DPLE Directive organizations such as telecommunications companies or airline carriers for which a stricter regime, the one of the GDPR, shall apply. Thirdly, with regard to the exclusion of the national security domain from the DPLE Directive, it was made clear that the exception shall not be misused to give a systematic legitimization to the processing of personal data falling outside the scopes of both the DPLE Directive and the GDPR. This implies that even though such a clause will be clarified by national legislators when implementing the DPLE Directive, a narrow interpretation would be recommended, as a safeguard against the risk of abuse or misuse.

Similarly, in its opinion 3/2015, WP29 points out a number of elements which follow the same reasoning of the EDPS in the Opinion mentioned above. ${ }^{19}$ On the concept of 'public security' for instance, WP29 considers it as a complementary police activity, next to the core mandate of criminal investigation and prosecution. However, such an addition to the scope of the DPLE Directive might carry on quite a broad interpretation of this wording by Member States: in some countries for instance, the administration of public health or food safety is considered as falling within the scope of the term public security, departing from some other domestic legislations which, as we will be able to see, include health in the notion of national security. Both WP29 and EDPS thus claimed that the vagueness surrounding the concept of public security may therefore lead to the expansion of the scope of the directive beyond matters and authorities dealing purely with criminal justice.

\section{Security in international law}

\footnotetext{
${ }^{17}$ Directorate General for Internal Policies Policy Department C, Citizen's Rights and Constitutional Affairs, National Security and Secret Evidence in Legislation and before the Courts: Exploring the Challenges, Study for the LIBE Committee 2014, <http://www.europarl.europa.eu/RegData/etudes/STUD/2014/509991/IPOL STU(2014)509991 EN.pdf> accessed 10 April 2019.

${ }^{18}$ EDPS (n 5).

${ }^{19}$ Article 29 Data Protection Working Party (n 6).
} 


\subsection{Theoretical bases from philosophy of law}

Philosophy of law and political theory do not often clearly distinguish between the concept of national security and the broad concept of security. Scholars have long debated on the boundaries between these two terms, many of them accepting that such an attempt has not brought meaningful results in the past ${ }^{20}$, some others criticizing the fact that a conceptual ambiguity was deliberately kept unclear for the benefit of policy-makers. ${ }^{21}$ This exercise is made even more difficult by the fact that legal scholarship has so far developed the two concepts at times ambiguously or interchangeably.

One of the first striking elements when reviewing the above-mentioned scholarly literature is the relation between national security and sovereignty in the post-Augsburg ${ }^{22}$ and post-Westphalian era. For example, Thomas Hobbes associates the two concepts extensively in its Leviathan. Before the age of governments, the world was populated by individuals in a state of nature, whereby each man enjoyed his personal sovereignty. ${ }^{23}$ This led to individuals being at war with each other, in a perpetual state of instability and, most importantly, insecurity. Men therefore needed some sort of collective security, and it was from this impulse that governments originated. The fil rouge between the individual (main entity in the nature state) and the government (main entity in the next era) is the legitimation of the state towards the concept sovereignty, which shifts from being a singular and individual attribute to a collective one. However, while Hobbes conceptualized this theory in defence of the monarchy under which he was living, others departed from his ideas in order to establish the perception that democratic governments cannot transcend from individuals and the enjoyment of their rights. John Locke, for instance, developed the principle of reciprocity between governments and society: sovereignty did not mean saving humankind from a previous tragic era ${ }^{24}$. Rather, it consisted of individuals entering into a mutual contract with reciprocal expectations, and the ultimate possibility to withdraw from it. The combination of these theories enables us to understand something fundamental. Sovereignty is seen as the expression of a state protecting the contract between itself and its citizens, not just a default attribution to each state-entity. For this reason, the government is accountable towards the citizens. Reflecting on this with modern eyes, this reasoning could have a translation in providing control to people with respect to the activities undertaken by the

\footnotetext{
${ }^{20}$ Klaus Knorr, 'National Security Studies: Scope and Structure of the Field', in Frank N. Trager and PhilipS. Kronenberg (eds.), National Security and American Society: Theory, Process and Policy (Lawrence, KS, 1973), p. 5.

${ }^{21}$ Barry Buzan, 'Peace, Power, and Security: Contending Concepts in the Study of International Relations' (1984) 21 Journal of Peace Research 109., p. 111

22 "Significant modernisation of the national security concept occurred upon the adoption of the Doctrine on the inviolability of sovereignty dating back to the Augsburg Peace in 1555, which gave the right to a sovereign to decide on the religion in his country (cuius region, eius religion - whose country, his religion). This right was confirmed and revised by the Prague Peace of 1635 and the Peace of Westphalia of 1648" Sasa Mijalkovic and Dusan Blagojevic, 'The Basis of National Security in International Law' [2014] Nauka, bezbednost, policija 49.

${ }^{23}$ Thomas Hobbes, Leviathan-Or the Matter, Form and Power of a Common-Wealth Ecclesiastical and Civil (1651) ed. by I Shapiro (New Haven, CT: Yale University Press, 2010).

${ }^{24}$ Alex Tuckness, 'Locke's Political Philosophy' in Edward N Zalta (ed), The Stanford Encyclopedia of Philosophy (Summer 2018, Metaphysics Research Lab, Stanford University 2018) <https://plato.stanford.edu/archives/sum2018/entries/locke-political/> accessed 20 May 2019.
} 
government on national security grounds. More specifically, national security and sovereignty are crucial elements of the identity of a government, although the exercise of these need some form of scrutiny against arbitrary and unaccountable powers.

The definition of national security (and its boundaries) has often taken different routes and interpretations, particularly in the last Century. For instance, definitions focused solely on the protection of a state from external threats ${ }^{25}$ (Harold Brown), or included also non-military coercions ${ }^{26}$ (Joseph Romm). Even in these conceptualizations, however, the link between national security and sovereignty keeps surviving. This correlation has become an established doctrine in international customary law, where sovereignty is one of the main legal principles to establish the integrity ${ }^{27}$ and the authority of a state to exercise its power without interferences ${ }^{28}$ (i.e., political independence and territorial integrity).

This assumption was further confirmed in the nineteen eighties by the approach to security by the Copenhagen School, the first group of international theorists to establish the securitization ${ }^{29}$ doctrine, according to which modern security substantiates in the tendency of states to transform unrelated subjects into security items. In this doctrine, three levels of security are identifiable: individual, state and international. The second one is the closest to the expression of national security. In his book People, States and Fear, Buzan takes a stance which acknowledges the complexity of security threats according to the referent object (i.e., the threatened actor situation) which looks at it. ${ }^{30}$ Such a methodological approach developed by the Copenhagen School, imposes to analyse what is the nature of a state, in order to delineate the contours of the threats under which a nation is subject to.

\subsection{International law}

\footnotetext{
${ }^{25}$ Harold Brown, 'U.S. National Security: The Next 50 Years', (2000), Paul H. Nitze Award Lecture, Center for Naval Analyses.

${ }^{26}$ Joseph J. Romm, 'Defining National Security: The Nonmilitary Aspects' (1993), Council on Foreign Relations Press

${ }^{27}$ Charter of the United Nations (signed 26 June 1945 , published 24 October 1945), 1 UNTS XVI (UN Charter), art 2(4).

${ }^{28}$ Samantha Besson, definition of 'Sovereignty', Oxford Public International Law, Published under the auspices of the Max Planck Foundation for International Peace and the Rule of Law under the direction of Rüdiger Wolfrum (last updated April 2011) <https://opil.ouplaw.com/view/10.1093/law:epil/9780199231690/law-9780199231690e1472> accessed 13 May 2019.

29 "The concept of securitization provided a fresh take on the increasingly tiresome debate between those who claimed that threats are objective (i.e., what really constitutes a threat to international security) on the one hand, and those that maintained that security is subjective (what is perceived to be a threat) on the other. In an attempt to sidestep or bypass this debate, the Copenhagen school suggests that security should instead be seen as a speech act, where the central issue is not if threats are real or not, but the ways in which a certain issue (troop movements, migration, or environmental degradation) can be socially constructed as a threat", Rens van Munster, definition of 'Securitization - International Relations - $\quad$ Oxford Bibliographies' <https://www.oxfordbibliographies.com/view/document/obo-9780199743292/obo-9780199743292-0091.xml> accessed 13 May 2019.

${ }^{30}$ Barry Buzan (Emeritus Professor at the London School of Economics and Political Science and Honorary Professor at the University of Copenhagen) is one of the most prominent scholars of the Copenhagen School alongside Professor Ole Waever.
} 
The theoretical considerations discussed in section 3.1 have a concrete translation into legal constructs and codification. ${ }^{31}$ Even though the law of international treaties has explored national security without attributing it a clear definition, a number of common approaches towards this subject can be found. For example, these can be inferred from the circumstances under which national security is invoked by states according to international treaties. National security is often included as a matter of exception, derogating from the adherence to an existing treaty obligation. Notwithstanding the fact that the room for manoeuvre of such an exception might vary from treaty to treaty, what is common is the explicitness of such an exception. As Ackerman argues, international customary law does not advocate an implicit national security exception into treaties. ${ }^{32}$ Even if the nature of national security clauses in international customary laws provides for a margin of appreciation, very often such a clause is not interpreted as fully arbitrary. Eisenhut observes this when he exegetically differentiates between circumscribed security exceptions and self-judging clauses, often laid down by the wording 'as it considers necessary'. ${ }^{33}$ Regardless of the breadth of such a discretion, however, Eisenhut identifies in all such examples the presence of judicial review mechanisms (including in the self-judging clauses). ${ }^{34}$

Having said this, it is also useful to give an overview of the security exceptions amongst some of the main international law treaties. The General Agreement on Tariffs and Trade (GATT) for instance, includes a number of highly disputed national security exceptions (article XXI - referring to 'essential security interests' $)^{35}$. The discretion that the self-judging clause leads to is not by-default absolute: according to a number of scholars, a WTO panel shall be entitled to evaluate the appropriateness of the invocation of this clause. ${ }^{36}$

Moving to another prominent treaty, the UN Charter includes among its primary objectives the promotion of international peace and security (inter alia, through the powers of the Security Council), where national security is seen as a concept misaligned from the collective protection of international security. Yet, the achievement of these global objectives also relate to the orderly maintenance of national interests, such

\footnotetext{
${ }^{31}$ Mijalkovic and Blagojevic (n 22).

${ }^{32}$ Rather, the exceptions that are consolidated by the Vienna Convention and the customary evolution of international law are normally substantiated into four different cases: rebus sic stantibus (change of circumstances), reprisal (violation of the treaty by another party), self-defence or necessity. See also, Susan Rose-Ackerman and Benjamin Billa, 'Treaties and National Security' (2018), reprinted in Yale Law School Faculty Scholarship Series, Paper 5954061.

33 Dominik Eisenhut, 'Sovereignty, National Security and International Treaty Law. The Standard of Review of International Courts and Tribunals with Regard to "Security Exceptions"' (2010) 48 Archiv des Völkerrechts 431.

${ }^{34}$ For instance, the ICJ reviewed the extent of a such an exemption in its widely known 'Nicaragua case', whereby the Court remarked that the application of the self-judging clause must not be intended as totally arbitrary; Case Concerning Military and Paramilitary Activities In and Against Nicaragua (Nicaragua v. United States of America); Jurisdiction of the Court and Admissibility of the Application, International Court of Justice (ICJ), 26 November 1984. ${ }^{35}$ To be exercised only when derogating from the disclosure of information on as nuclear materials, military goods or in case of emergency in the self-determination of a state in foreign affairs. See also Michael J Hahn, 'Vital Interests and the Law of GATT: An Analysis of GATT's Security Exception' (1991) 12 Michigan Journal of International Law 558. ${ }^{36}$ Brandon J Murrill, 'The "National Security Exception" and the World Trade Organization' (2018), 5. Brandon J Murrill, 'The "National Security Exception" and the World Trade Organization' (2018), 5.
} 
as state's self-determination and sovereignty. ${ }^{37}$ While article 39 provides for a number of prerequisites for the Council's military powers to be actionable against a threat for international peace and security, article 51 counterweights such a global vision of security, allowing for the exercise of the inherent right of self-defence, whereby an individual state may use the force to counter an armed attack prior to any Security Council action. ${ }^{38}$

The International Covenant on Civil and Political Rights (hereafter, the 'Covenant'), is one of the first and main instruments for the international protection of civil rights, including the right to privacy. ${ }^{39} \mathrm{~A}$ general derogation for public emergencies is laid down in article 4. It enables the unilateral departure from the rights enshrined in the Covenant while conditioning it to a number of safeguards. ${ }^{40}$ Moreover, national security is mentioned as a way to exception to the exercise of a number of rights ${ }^{41}$, to be invoked only insofar as it is "taken to protect the existence of the nation or its territorial integrity or political independence against force or threat of force" ${ }^{42}$. The invocation of these clauses is circumscribed and applied under specific conditions ${ }^{43}$. Two points of reflection are worth mentioning here. Firstly, that the wording of the Covenant in such exceptions clearly differentiates between national security as a distinct concept from public order. ${ }^{44}$ Secondly, the interference with the right to privacy (article 17) does not mention national security. Yet, the General Note on article 17 provided by the Human Rights Committee, explains that interferences shall be provided by law and even in such case, must not be arbitrarily conducted, rather designed in accordance with the principles laid down by the Covenant. ${ }^{45}$ Furthermore, the UN Special Rapporteur for the right to privacy has further clarified the meaning of article 17 in the national security context: the latest Report in fact conceptualizes the need for an extension of the

\footnotetext{
${ }^{37}$ Mijalkovic and Blagojevic (n 22).

38 UN Charter, art 51: "Nothing in the present Charter shall impair the inherent right of individual or collective selfdefence if an armed attack occurs against a Member of the United Nations, until the Security Council has taken measures necessary to maintain international peace and security. Measures taken by Members in the exercise of this right of self-defence shall be immediately reported to the Security Council and shall not in any way affect the authority and responsibility of the Security Council under the present Charter to take at any time such action as it deems necessary in order to maintain or restore international peace and security".

${ }^{39}$ Comments and references: Claire Macken, 'Preventive Detention and the Right of Personal Liberty and Security under the International Covenant on Civil and Political Rights, 1966' (2005) 26 Adelaide Law Review 1.; United Nations, General Comment No. 16 art 17 (The right to respect of privacy, family, home and correspondence, and protection of honour and reputation).

${ }^{40}$ Rose-Ackerman and Billa (n 32).

${ }^{41}$ Freedom of movement (art 12), right to judicial redress after an expulsion (art 13), publicity of trials (art 14), freedom of expression (art 19), freedom of association (art 22).

42 UN Sub-Commission on Prevention of Discrimination and Protection of Minorities, Siracusa Principles on the Limitation and Derogation of Provisions in the International Covenant on Civil and Political Rights Annex, UN Doc E/ CN.4/1984/4 (1984), as reported in CCBE Recommendations on the protection of fundamental rights in the context of 'national security' - 2019, p.6

${ }^{43}$ Specifically, the interference with the right must be foreseen by a law and it must pass the necessity test.

${ }^{44}$ International Covenant on Civil and Political Rights, arts. 12, 14, 19 and 22.

45 United Nations, General Comment No. 16 art 17 (The right to respect of privacy, family, home and correspondence, and protection of honour and reputation), arts. 3 and 4.
} 
oversight powers of regulatory agencies involved in national security. ${ }^{46}$ In its recommendations, the Rapporteur Joe Cannataci suggests the adoption of the principle "If it's exchangeable, then it's oversightable, in relation to any personal information exchanged between intelligence services and law enforcement agencies within a country, and across borders" ${ }^{47}$ This underscores the increasing intersection between national security and law enforcement tasks in cross-border setting, on the one hand, and the call for extension of oversight powers over such practices, on the other. ${ }^{48}$

\subsection{Council of Europe}

In the same vein, in the European Convention of Human Rights (hereinafter ECHR), national security is included as an exception to the full enjoyment of the rights enshrined in the Convention. However, such a clause can only be exercised when explicitly mentioned, since a number of rights are defined as absolute, hence inalienable and non-derogable, such as the prohibition against torture or slavery (articles 3 and 4.1) and against unlawful punishment (article 7). ${ }^{49}$ Beyond such absolute rights, the ECHR provides for a number of other civil and human principles which are instead either limited (i.e. circumscribed to a specific case, such as article 5 - right to liberty) or qualified (i.e., which need to be balanced with other interests, such as article 8 - respect for private life). When the interference with the latter category occurs, such a violation must meet the legality and necessity tests (foreseeable law and proportional measure to the end to be achieved), in order to be accepted. Within this strict interpretation of the interference, the ECHR mentions national security as an explicit cause for interfering with a qualified right on a number of occasions: article 8 (private life), article 10 and 11 (freedoms of expression, assembly and association).

A first consideration to be made, refers to the wording of the ECHR in articles 8,10 and 11. Next to national security, the ECHR explicitly lays down the term 'public safety', as well as the 'prevention of disorders and crimes'. In article 10 and 11, the grounds are even more articulated, including as a standalone concept the notion of 'territorial integrity' (an inherent element of the principle of sovereignty). Public safety and order and the protection of health and morals could be accumulated under the umbrella of public security. ${ }^{50}$ However, delineating boundaries cannot be clearly drawn, while the States and Convention organs do not consider these clauses to be mutually exclusive. In this manner, a State would be able to invoke collectively national security and, for instance, public safety. ${ }^{51}$

\footnotetext{
${ }^{46}$ Human Rights Council, 25/117 Panel on the right to privacy in the digital age (2014) A/HRC/25/117.

${ }^{47}$ Human Rights Council, Report of the Special Rapporteur on the right to privacy (2019), A/HRC/40/63.

48 'OHCHR I States Must Bridge Privacy Gap in Intelligence Sharing, Says UN Human Rights Expert' <https://www.ohchr.org/EN/NewsEvents/Pages/DisplayNews.aspx?NewsID=24242\&LangID=E> accessed 2 April 2019.

49 John Finnis, 'Absolute Rights: Some Problems Illustrated' (2016) 61 American Journal of Jurisprudence 195.

${ }^{50}$ Sofie Stalla-Bourdillon 'Privacy Versus Security ... Are We Done Yet?', in Sophie Stalla-Bourdillon, Joshua Phillips, Mark D. Ryan (eds), 'Privacy vs. Security' (Springer London, Springer Briefs in Cybersecurity 2014), p. 69.

${ }^{51}$ Iain Cameron, 'National Security and the European Convention on Human Rights', (Kluwer Law International 2000), p. 54.
} 
Furthermore, when national security is invoked by a State, judicial scrutiny by the ECtHR over such an exercise is foreseen. In the context of the ECHR, this translates into a narrow interpretation of the exceptions laid out in article 8, for example. It would go beyond the scope of this chapter to analyse indepth the rather longstanding series of decisions of the European Court of Human Rights on this, even though it is important to mention the Klass $v$ Germany case, where the ECtHR, in evaluating a German surveillance law against the legality test of the $\mathrm{ECHR}^{52}$, asserted that national security exceptions shall be assessed narrowly and shall exclude that "Contracting States enjoy an unlimited discretion". ${ }^{53}$ The prohibition of unlimited discretion goes even further in certain domains, for instance with regard to the over-classification of documents, whereby "[T]he individual must be able to challenge the executive's assertion that national security is at stake", as elaborated by the Court in the Janowiecz case ${ }^{54}$. The ECtHR, therefore, does not by default provide for a wider margin of appreciation to States on acts of national security in contrast to acts of public security. Moreover, it should be noted that neither the ECHR defines national security in any way, nor the ECtHR discusses what sort of initiative constitutes a measure of national security. The Court relies rather on the Contracting States' claim that the measure in question aims to serve national security. ${ }^{55}$ Nonetheless, espionage, terrorism, ${ }^{56}$ subversion $^{57}$, separatist organisations ${ }^{58}$, and inciting disaffection of military personnel ${ }^{59}$ have been accepted by the Court as threats against national security.

The Convention 108 is a Council of Europe international instrument signed in 1981 for the protection of individuals against the automatic processing of personal data. ${ }^{60}$ The Convention served as the basis for the modernization of data protection laws and policies for a very long time. After more than thirty years, in 2018 a significant modernization of the Convention was published in the form of the so-called Convention 108+. In comparing the two texts, a number of meaningful elements can be observed. To begin with, the term national security now replaces the old wording state security. However, the two concepts seem to overlap in terms of purposes, as Convention 108+ provides for the same exact exemptions as the 108 (fair and lawful processing, safeguard against special categories of data processing, information rights), alongside additional ones (data breach notifications, trans border data transfers notifications, enforcement powers of supervisory authorities). ${ }^{61}$ While the same boundaries to as the ones in the ECHR apply (legality, necessity and proportionality), it is noteworthy to observe that, such

\footnotetext{
52 Rose-Ackerman and Billa (n 32).

53 Klass and others v. Germany, App. No. 5029/71 (ECHR, 6 September 1978), paras 49-50.

54 Janowiec and Others v. Russia, App. No. 55508/07 29520/09 (ECHR, 21 October 2013), paras 213-214.

55 Iain Cameron (n 51), p. 36; Lyubomira Midelieva, 'The Elusive Cause and the Extensive Effect of the Principle of Supremacy of EU Law' (2017) 7 Southampton Student Law Review 21.

${ }^{56}$ Klass and others v. Germany, App. No. 5029/71 (ECHR, 6 September 1978), paras 49-50.

${ }^{57}$ Leander v. Sweden, App. No. 9248/81 (ECHR, 26 March 1987).

58 United Communist Party of Turkey and others v. Turkey, App. No. 19392/92 (ECtHR, 30 January 1998).

${ }^{59}$ Arrowsmith v. the United Kingdom, App. No. 7075/75 (ECtHR, 12 October 1978).

${ }^{60}$ Convention for the Protection of Individuals with regard to Automatic Processing of Personal Data, ETS No. 108, Strasbourg, 28/01/1981.

${ }^{61}$ Convention for the protection of individuals with regard to the processing of personal data - Convention $108+$, 128th session of the Committee of Ministers, Elsinore, 18 May 2018.
} 
exceptions are formulated less broadly than in the previous text, and protected by a number of more strict conditions, as confirmed by the wording of article 11 of the Convention 108+ and the recommendations made by the UN Special Rapporteur for the Right to Privacy in his recent reports. ${ }^{62}$

\section{Security in European Union law}

\subsection{EU treaties}

The Treaty of the European Union (TEU), in its article 4(2), calls for the respect by the European Union for Member States' national identity and sovereignty. Member States are the first and foremost holders of their prerogatives towards their own national security. ${ }^{63}$ However, it is believed that such derogations to EU Law do not fully exclude the principle of supremacy of EU Law64: "Despite the inclusion of a national identity clause in Article 4(2) TEU (...) EU law still does not permit Member States to unilaterally decide to override EU obligations and give precedence to measures of national law, however framed" ". ${ }^{65}$ Yet, in the operationalization of EU primary and secondary law, this means that national security in article 4(2), provides for a level of derogatory legislative and executive autonomy for Member States ("In particular, national security remains the sole responsibility of each Member State"), one which can be characterized by the exceptionality of the action under such realm. ${ }^{66}$ Even though the following considerations are, at the time of writing, being challenged before the Court of Justice of the EU (ECJ) as will be explained subsequently ${ }^{67}$, it is useful to remark that part of the European legal tradition has so far agreed that article 4(2) excludes the applicability of basic EU privacy principles, such as article 8 of the EU Charter (right to protection of personal data) and article 16 of the Treaty on the Functioning of the European Union (TFEU) (protection of personal data) "to any national security matters governed by domestic law". ${ }^{6}$

\footnotetext{
${ }^{62}$ Human Rights Council, Report of the Special Rapporteur on the right to privacy (2019), A/HRC/40/63, para. 28.

${ }^{63}$ Consolidated version of the Treaty on the Functioning of the European Union, 2016, OJ C 202, (Treaty on the Functioning of the European Union), art 73.

${ }^{64}$ See also: Midelieva (n 55).

${ }^{65}$ Monica Claes, 'The Primacy of EU Law in European and National Law' [2015] The Oxford Handbook of European Union Law <http://www.oxfordhandbooks.com/view/10.1093/oxfordhb/9780199672646.001.0001/oxfordhb9780199672646-e-8> accessed 5 April 2019.; Christopher Kuner , Fred Cate, Orla Lynskey, Christopher Millard, Nora Ni Loideain and Dan Svantesson, 'An Unstoppable Force and an Immoveable Object? EU Data Protection Law and National Security' 3.Barbara Guastaferro, 'Beyond the Exceptionalism of Constitutional Conflicts: The Ordinary Functions of the Identity Clause' (2012) Yearbook of European Law 263-318 and Monica Claes, 'National Identity: Trump Card or Up for Negotiation?' in Alejandro Saiz Arnaiz and Carina Alcoberro Llivina, National Constitutional Identity and European Integration (2013), Intersentia 109-140

${ }^{66}$ Consolidated version of the Treaty on European Union, 2016, OJ C 202, (Treaty on European Union), art 4(2).

${ }^{67} \mathrm{C}-623 / 17$ Privacy International v Secretary of State for Foreign and Commonwealth Affairs and Others, 31.10.2017; C-512/18 French Data Network, La Quadrature du Net, Fédération des fournisseurs d'accès à Internet associatifs v Premier ministre, Garde des Sceaux, Ministre de la Justice, 03.08.2018; C-520/18 Ordre des barreaux francophones et germanophone, Académie Fiscale ASBL, UA, Liga voor Mensenrechten ASBL, Ligue des Droits de l'Homme ASBL, VZ, WY, XX v Conseil des ministers, 02.08.2018.

${ }^{68}$ Christopher Kuner and others ( $n$ 65).
} 
The TFEU moreover considers security as an exception that derogates from EU competence. It does so in at least two occasions. On the one hand, article 346 TFEU, allows for an exception to be made in order to prevent the supply of information by a Member State that is contrary to the 'essential interests of its security', and article 347 TFEU calls upon the Member State to fulfil its obligations in the area of protection of international security. On the other hand, 'public security' may be invoked as an exception to the main rules and freedoms that the EU Internal Market brings forward. ${ }^{69}$ It should be noted here that the freedom of movement of persons established in the TFEU has been codified in secondary law, that is in Directive $64 / 224 /$ EEC, which has been repealed by the currently in force Directive 2004/38/EC. ${ }^{70}$ These legal instruments include the same terminology and reference to 'public security' as the TFEU and have given rise to a plethora of rulings by the Court of Justice of the European Union (ECJ), to which mention will be made as follows.

In his analysis on the exceptions to the EU free movement law, Koutrakos (2016) strikes a noteworthy point in referring to the meaning of 'security' deriving from the TFEU as the closest principle to the concept of state sovereignty, encompassing both internal and external security. ${ }^{71}$ On the contrary, another scholarly (Dimitrova and Brkan) approach assimilates 'public security' within the meaning of the Treaty to the security of the European public, its citizens and the EU territory. According to the latter, while national security may only revolve around the security of each individual Member State, public security may also be considered as a broader term encompassing the security within the whole EU. ${ }^{72}$ These two different interpretations demonstrate the complexity surrounding the concepts of national security and public security, as well as the flexibility in which they may be understood depending on the context.

A final remark should be made in relation to the changes the Lisbon Treaties brought in regulating aspects of security. In particular, the role of the EU on matters of internal security and criminal law was strengthened through various institutional changes. Besides, offering an area of freedom, security and justice to EU citizens lays amongst the highest priorities of the EU. ${ }^{73}$ On the one hand, the 'Common Foreign and Security Policy' (hereinafter CFSP) ${ }^{74}$ acquired a stronger structure and position, as will be explained below under 'EU Policy'. On the other hand, the EU has now been conferred upon the brand-

\footnotetext{
${ }^{69}$ Treaty on the Functioning of the European Union, arts 36, 45, 52 and 65 . These provisions allow for limitations to the free movement of goods, workers, services and capital respectively on grounds of public security.

${ }^{70}$ Directive 2004/38/EC of the European Parliament and of the Council of 29 April 2004 on the right of citizens of the Union and their family members to move and reside freely within the territory of the Member States amending Regulation (EEC) No 1612/68 and repealing Directives 64/221/EEC, 68/360/EEC, 72/194/EEC, 73/148/EEC, 75/34/EEC, 75/35/EEC, 90/364/EEC, 90/365/EEC and 93/96/EEC (Text with EEA relevance), OJ L 158, 30.4.2004, p. 77.

${ }^{71}$ Panos Koutrakos (2016) ‘Public Security Exceptions and EU Freed Movement Law', in P. Koutrakos, N. Nic Shuibhne \& P. Syrpis (Eds.) Exceptions from EU Free Movement Law: Derogation, Justification and Proportionality (Modern Studies in European Law), Oxford: Hart Publishing, 190.

72 Anna Dimitrova and Maya Brkan (2017) 'Balancing National Security and Data Protection: The Role of EU and US Policy-Makers and Courts before and after the NSA Affair', Journal of Common Market Studies, 751.

${ }^{73}$ Treaty on European Union, art 3(2).

${ }^{74}$ Treaty on European Union, Title V.
} 
new competence to define criminal offences in areas of particularly serious crime with a cross-border dimension, including terrorism. ${ }^{75}$ It could then be concluded that, within this framework, the EU is moving towards a broader concept of security that encompasses all threats to its citizens, while national security remains confined to the limits of strictly state-related threats.

\subsection{Jurisprudence on security as derogation}

The examples from the TFEU help us understand how the European legislator might deliberately have relinquished the definition of national and public security, probably in favour of further contextualization by both jurisprudence and EU policy. More specifically, with regard to the judicial approach on security as a derogation, the ECJ has always tried to provide for a narrow interpretation of the exceptions at stake, although very few details explain us what national security really is with regard to European Union Law ${ }^{76}$. As the Council of Bars \& Law Societies of Europe fairly points out ${ }^{77}$, the Court has never clearly defined national security except for providing it a collective scope in the Promusicae $v$ Telefonica case, whereby it states that "national security [...] constitutes activities of the State or of State authorities unrelated to the fields of activity of individuals"78.

Furthermore, in examining the security derogation within the meaning of the TFEU, the ECJ seems to endorse the doctrine under which any sort of security (either public or national) represents a dynamic and flexible concept that often tends to evolve or adapt to the circumstance or the legal scenario, thus imposing a case-by-case approach in its assessment. ${ }^{79}$ For instance, in the Commission $v$ Spain, a case before the ECJ about a person that was refused a visa on public security grounds, the Court explained that any measure taken on the grounds of public security should comply with the proportionality principle and not be based solely on an individual's conduct. ${ }^{80}$ Therefore, Member States should corroborate the mere public security argument with additional information to assess the criminal predisposition of the individual. ${ }^{81}$

Later on, however, the Court found in Tsakouridis that public security could be affected by " $a$ threat to the functioning of the institutions and essential public services and the survival of the population, as well as the risk of a serious disturbance to foreign relations or to peaceful coexistence of nations, or a risk to

\footnotetext{
${ }^{75}$ Treaty on the Functioning of the European Union art 83.

${ }^{76}$ See Case C-72/83, Campus Oil Limited and others v Minister for Industry and Energy and others, [ 1984] ECR 1984 -02727; Case C-112/91, Hans Werner v Finanzamt Aachen-Innenstadt , [1993] ECR 1993 I-00429. See also: Eisenhut (n 33).

${ }_{77}$ CCBE Recommendations on the protection of fundamental rights in the context of 'national security' - 2019, p.8

${ }^{78}$ Case C-275/06, Productores de Música de España (Promusicae) v Telefónica de España SAU, [2008] ECR I-00271, par. 51

${ }^{79}$ Case C- 30-77, Régina v Pierre Bouchereau, [1977] ECR 1977 -01999

${ }^{80}$ Case C-503/03 Commission of the European Communities v Kingdom of Spain, [2006] ECR I-01097

${ }^{81}$ 'Wyatt and Dashwood's European Union Law: Alan Dashwood: Hart Publishing' <https://www.bloomsbury.com/in/wyatt-and-dashwoods-european-union-law-9781847317667/> accessed 13 May 2019. p. 482 to 485.
} 
military interests" ${ }^{82}$ These elements point to the interpretation that assimilates public security within the meaning of the TFEU to national security, as described above. Finally, the ECJ recently associated the concept of public security with the idea of fundamental interests of society, in another case on permissible derogations from the freedom of movement. ${ }^{83}$ In particular, a threat to public security may include " $a$ particularly serious threat to one of the fundamental interests of society". Interestingly, this approach has been implemented in the recitals of the DPLE Directive. ${ }^{84}$ It has been argued, however, that the Court is adopting a very broad concept of public security, while this 'socialisation' of the concept strips public security from the very element that differentiates it from the notion of public policy. ${ }^{85}$ These rulings are indicative of the room for manoeuvre the ECJ enjoys in interpreting (public) security as a derogation to fundamental freedoms of the EU Internal Single Market.

\subsection{EU Policy}

A report from LIBE Committee of the European Parliament, aiming to analyse Member States' definition of national security, states that the term "is nebulously defined across the Member States analysed, with no national definition meeting legal certainty and 'in accordance with the law' standards and a clear risk that the executive and secret services may act arbitrarily" ${ }^{86}$ Furthermore, the report argues that, whilst the term national security in the 50es was contextualized by any form of war threat from another stateactor, in the following decades the concept got "broadened to include criminal activities, terrorism and migration". A change that, as observed by Bigo (1994), was also perceived in the evolution of European policing measures and strategies (which followed the evolution of historical events), changing from a mono-dimensional concept of security, typical for the Cold War, into a more sophisticated one, which takes into account modern challenges and hybrid threats, such as cross-border criminality and massive migrations. ${ }^{87}$

While national security remains a prerogative of Member States('domaine reserve', as Eisenhut puts it ${ }^{88}$ ), small steps ahead by the European Union have been made with the establishment of the CFSP, whereby for the EU arrogates itself the intergovernmental lead in the rollout of a pan-EU framework on security and defence. ${ }^{89}$ In particular, the European Union has been assigned the task of ensuring a high level of security throughout a mandate that affirms the principles of shared and attributed competences, by ways of actions aimed at preventing crime, enabling police cooperation, supporting mutual judicial recognition

${ }^{82}$ Case C-145/09, Land Baden-Württemberg v. Panagiotis Tsakouridis, [2010] ECR I-11979.

83 Case C-348/09, P.I. v Oberbürgermeisterin der Stadt Remscheid, [2012], ECR General.

${ }^{84}$ Directive (EU) 2016/680, rec 12.

85 Loïc Azoulai and Stephen Coutts (2013) 'Restricting Union citizens' residence rights on grounds of public security. Where Union citizenship and the AFS meet: P.I.' Common Market Law Review, 50(2), 553.

${ }^{86}$ Study for the LIBE Committee (n 17); EDPS (n 5).

${ }^{87}$ Didier Bigo (1994), 'The European internal security field: stakes and rivalries in a newly developing area of police intervention', in M. Anderson and M. den Boer (eds), Policing Across National Boundaries (London: Pinter), 161.

${ }^{88}$ Eisenhut (n 33).

${ }^{89}$ Mary Dobbs (2014) 'Sovereignty, art 4(2) TEU and the respect of national identities: Swinging the balance of power in favour of the member states?', Yearbook of European Law, 33(1), 298. 
and approximating criminal laws. ${ }^{90}$ To date, such powers are limited to coordination only, and are highly susceptible to changes according to the evolution of the political scenario ${ }^{91}$, including on the definition and adoption of common policies on cyber defence $e^{92}$.

What comes to light however is that the EU as a policy maker has not defined national security (probably, deliberately), derogating this exercise to the events and the circumstances of the moment. As we will see, such an approach is recurrent in many international and national ${ }^{93}$ law instruments. However, this does not mean that the security exceptions in EU law do not give us any meaningful indication. To start with, national security in EU law might be intended as a concept which needs contextualization, more specifically legal operationalization. Secondly, even though national and public security shall be regarded as exceptions, scrutiny by the ECJ shall still be expected, particularly with regard to the proportionality of the call for exception by the Member State. Having outlined the state of the art of EU primary law, jurisprudence and CFSP, it is useful to draw now from other sources of law, to verify how we can consolidate some of the details listed above and further explore how data-specific branches of EU secondary law regard national and public security as legal concepts.

\subsection{Security and personal data in secondary EU law}

In order to be able to understand the scope of the DPLE Directive and to examine to what extent the aforementioned analysis on the interpretation of national and public security may be similarly applied on secondary law and by extension on the text of the directive, further research was conducted on the mention of these two concepts and their role and potential meaning, in the following legal instruments:

\footnotetext{
${ }^{90}$ According to arts 2-6 Treaty on the Functioning of the European Union, the EU enjoys three types of competences, exclusive, shared and supporting. However, the Common Foreign and Security Policy is considered to constitute a sui generis type of competence.

${ }^{91}$ Stephen Weatherill, 'Distinctive Identity Claims, Article 4(2) TEU (and a Fleetingly Sad Nod to Brexit) Editorial Note' (2016) 12 Croatian Yearbook of European Law and Policy VII.

${ }_{92}$ Steven Blockmans, What Comes after the Last Chance Commission? Policy Priorities for 2019-2024. (Centre for European Policy Studies 2019)., Krzysztof Feliks Sliwinski, 'Moving beyond the European Union's Weakness as a Cyber-Security Agent' (2014) 35 Contemporary Security Policy 468.

${ }_{93}$ For instance, as Earl Howe (UK Government) states with regard to the situation in Britain: "It has been the policy of successive Governments not to define National security in statute. National security is one of the statutory purposes of the security and intelligence agencies". Earl Howe, Parliamentary debate on the Investigatory Powers Bill (2017), as reported in CCBE Recommendations on the protection of fundamental rights in the context of 'national security' -2019.
} 
GDPR $^{94}$, DPLE Directive ${ }^{95}$, E-Privacy Directive ${ }^{96}$, Regulation (EU) 2018/1725 ${ }^{97}$, Regulation on EUROPOL ${ }^{98}$, Framework Decision ${ }^{99}$, Data Retention Directive ${ }^{100}$, Anti-Money Laundering Directive ${ }^{101}$, PNR Directive ${ }^{102}$ and Agreements ${ }^{103}$, and Privacy Shield ${ }^{104}$. These instruments have been selected as components of the overarching EU regime establishing rules on the processing of personal data altogether as well as within specific sectors or institutions, and within specific contexts. A deeper focus on the relevant provisions of the DPLE Directive will be provided in the following section of this chapter.

Overall, national security, often also referred to as State security ${ }^{105}$, and public security are mentioned on most occasions side by side without an accompanying definition or differentiation in treatment. More specifically, manifestations of security function as permissible derogations to the application either of the instrument in its totality or of specific provisions, referring namely to the rights of individuals. The GDPR and the DPLE Directive, as aforementioned, explicitly foresee an exemption from the application of the rules they establish, in the context of national security, as falling outside the scope of the EU competences. ${ }^{106}$ It is worth mentioning that, formerly, activities of public security were also excluded

${ }^{94}$ Regulation (EU) 2016/679.

${ }^{95}$ Directive (EU) 2016/680.

${ }^{96}$ Directive 2002/58/EC of the European Parliament and of the Council of 12 July 2002 concerning the processing of personal data and the protection of privacy in the electronic communications sector (Directive on privacy and electronic communications), OJ L 201, 31/07/2002, 37.

${ }^{97}$ Regulation (EU) 2018/1725 of the European Parliament and of the Council of 23 October 2018 on the protection of natural persons with regard to the processing of personal data by the Union institutions, bodies, offices and agencies and on the free movement of such data, and repealing Regulation (EC) No 45/2001 and Decision No 1247/2002/EC (Text with EEA relevance.) PE/31/2018/REV/1, OJ L 295, 21.11.2018, 39.

${ }^{98}$ Regulation (EU) 2016/794 of the European Parliament and of the Council of 11 May 2016 on the European Union Agency for Law Enforcement Cooperation (Europol) and replacing and repealing Council Decisions 2009/371/JHA, 2009/934/JHA, 2009/935/JHA, 2009/936/JHA and 2009/968/JHA, OJ L 135, 24.5.2016, 53.

${ }^{99}$ Council Framework Decision 2008/977/JHA of 27 November 2008 on the protection of personal data processed in the framework of police and judicial cooperation in criminal matters, OJ L 350, 30.12.2008 (Council Framework Decision 2008/977/JHA).

100 Directive 2006/24/EC of the European Parliament and of the Council of 15 March 2006 on the retention of data generated or processed in connection with the provision of publicly available electronic communications services or of public communications networks and amending Directive 2002/58/EC, OJ L 105, 13.4.2006, 54.

${ }^{101}$ Directive (EU) 2018/843 of the European Parliament and of the Council of 30 May 2018 amending Directive (EU) 2015/849 on the prevention of the use of the financial system for the purposes of money laundering or terrorist financing, and amending Directives 2009/138/EC and 2013/36/EU (Text with EEA relevance), PE/72/2017/REV/1, OJ L 156, 19.6.2018, 43.

102 Directive (EU) 2016/681.

${ }^{103}$ Agreement between the European Union and Australia on the processing and transfer of Passenger Name Record (PNR) data by air carriers to the Australian Customs and Border Protection Service, OJ L 186, 14.7.2012, 4 and Agreement between the United States of America and the European Union on the use and transfer of passenger name records to the United States Department of Homeland Security, OJ L 215, 11.8.2012, 5.

104 Commission Implementing Decision (EU) 2016/1250 of 12 July 2016 pursuant to Directive 95/46/EC of the European Parliament and of the Council on the adequacy of the protection provided by the EU-U.S. Privacy Shield (notified under document C(2016) 4176) (Text with EEA relevance), C/2016/4176, OJ L 207, 1.8.2016, 1.

105 Directive 2006/24/EC, rec 4, 9; Directive 2002/58/EC, rec 11 and art 15(1); Council Framework Decision 2008/977/JHA, rec 5.

106 (n 14). 
from application as falling outside the scope of EU law. ${ }^{107}$ It can also be observed that older texts refer to the ECHR and follow the verbal construction of article 8(2) ECHR; a reference that faded away in most recent laws. Finally, both national and public security may be invoked to restrict data subject rights and namely the right of access in many of these instruments, including the GDPR, the DPLE Directive and the PNR Agreements.

The particularities presented in some of these legal instruments, nonetheless, should be given separate consideration. Some light on which elements may constitute national security is shed through its link to intelligence services and their activities ${ }^{108}$, as made by the legal texts of the Framework Decision, the Regulation on EUROPOL and the Privacy Shield. ${ }^{109}$ Interestingly, there is no mention of intelligence activities being exempted from application of the DPLE Directive, especially in light of the pending cases before the ECJ as will be discussed subsequently. Furthermore, the relevant EU legislative initiatives in the context of counter terrorism, i.e. the PNR Directive and the AML Directive, refrain from referencing to the terms of national and public security, rather they focus on the fight against (serious) crime including terrorism. For instance, the objectives of the PNR Directive is to "ensure the security and the safety of the public and ultimately to enhance the internal security of the EU". ${ }^{110}$

Bringing all these elements together, the ECJ is also called upon giving an answer to what national and public security comprise of in the field of data protection. In its now famous rulings on bulk transfers of electronic communications data from the service providers to law enforcement authorities, i.e. Digital Rights Ireland ${ }^{111}$ and Tele 2 Sverige / Watson ${ }^{112}$, the ECJ acknowledges that the legitimate aim of public security includes the fight against serious crime, in particular organised crime and terrorism. Furthermore, the ECJ has provided through these rulings a set of criteria to which law enforcement authorities must abide in order to collect electronic communications data in bulk. The question that has been recently raised, however, by three Member States, is whether these criteria may be also applicable vis-à-vis intelligence services and hence in the context of national security. ${ }^{113}$ Three references for preliminary request currently pending before the ECJ could potentially further blur the lines between national and public security. In this regard, Kuner (2018) argues that the Tele 2 Svergie / Watson ruling could already allow for a broad interpretation of public security, one that would encompass national security as well. ${ }^{114}$

\footnotetext{
107 Directive 2002/58/EC, art 1(3) and Council Framework Decision 2008/977/JHA, rec 5.

${ }^{108}$ Traditionally law enforcement authorities are entrusted with internal security and safety and are regulated more transparently under a stronger judicial oversight. On the contrary, intelligence services are competent on matters of national security against external threats, while they also operate with a higher degree of secrecy and enjoy wider discretion with limited judicial control.

109 See for example Council Framework Decision 2008/977/JHA art 1(4) 'This Framework Decision is without prejudice to essential national security interests and specific intelligence activities in the field of national security'. ${ }^{110}$ Directive (EU) 2016/681, rec 5-6.

${ }^{111}$ Case C-293/12 Digital Rights Ireland Ltd v Minister for Communications, Marine and Natural Resources and Others and Kärntner Landesregierung and Others, 8 April 2014, para 51.

112 Case C-203/15 and C-698/15 Tele2 Sverige AB v Postoch telestyrelsen and Secretary of State for the Home Department v Tom Watson and Others, [2016] ECR General, para 111.

${ }^{113}$ (n 67).

${ }^{114}$ Christopher Kuner and others ( $n$ 65).
} 
In this vein, the recently adopted Regulation on the free flow of non-personal data, in contrast to the above listed instruments, is the only one providing for a formal definition of public security in its body of recitals. ${ }^{115}$ Public security serves also in this case as a ground for derogation from the rules established by said Regulation, which states that "the concept of public security, within the meaning of Article 52 TFEU and as interpreted by the Court of Justice, covers both the internal and external security of a Member State, as well as issues of public safety, in order, in particular, to facilitate the investigation, detection and prosecution of criminal offences". ${ }^{116}$ The texts continues by explaining that public security "presupposes the existence of a genuine and sufficiently serious threat affecting one of the fundamental interests of society, such as a threat to the functioning of institutions and essential public services and the survival of the population, as well as the risk of a serious disturbance to foreign relations or the peaceful coexistence of nations, or a risk to military interests".

This definition further complicates matters in a twofold manner. Firstly, by introducing the concept of safety as part of public security. Like the notion of security, safety is also what scholars call 'a contested concept'. Even though sometimes the two notions can be used interchangeably, law and security disciplines tend to differentiate between them. With regard to safety, Van den Berg and Prins (2017) consider it as the protection from inadvertent flaws and mistakes which can cause an accidental harm to individuals in a determined situation. ${ }^{117}$ Secondly and most importantly, public security within these lines is essentially equated to national security. While in line with the interpretations provided above, this definition bears a fundamental controversy if applied in the context of the DPLE Directive.

\subsection{EU Member States}

The EU Member States, in their turn, conceptualise national security through a number of different legal instruments within their legal regimes. Several derive this notion from constitutional law, some embed it into secondary legislation pertaining on defence and the military, while others formulate national security as an exception to law enforcement statutes. Recently, a study conducted by the Council of Bars \& Laws Societies of Europe (CCBE), tried to look into the various Member States notions of national security. ${ }^{118}$

\footnotetext{
115 Regulation (EU) 2018/1807 of the European Parliament and of the Council of 14 November 2018 on a framework for the free flow of non-personal data in the European Union (Text with EEA relevance.), PE/53/2018/REV/1, OJ L 303, 28.11.2018, 59.

${ }^{116}$ Regulation (EU) 2018/1807, rec 19.

${ }^{117}$ While within the term security the 'acquired values' are harmed deliberately, safety describes instead a protection from a circumstance where the source of the danger is not necessarily human, with the subsequent exclusion of the intentional element in the conceptualization of the term. It is important to note that many challenges of our modern world are the result of a combined failure from both security and safety: Van den Berg and Prins (2017) well describe this with the example of the Fukushima events in 2011, where a tsunami caused by an earthquake provoked a chain reaction that led to a nuclear disaster. In this example, the clearly unintentional course of natural events mixed with human negligence and unpreparedness, putting at risk a significant number of human lives. 'A Multi-Actor Perspective on Security and Safety - Perspectives and Levels' (Coursera) $<$ https://www.coursera.org/lecture/security-safety-globalized-world/a-multi-actor-perspective-on-security-andsafety-duiLA> accessed 13 May 2019.

118 CCBE Recommendations on the protection of fundamental rights in the context of 'national security' (2019) https://www.ccbe.eu/fileadmin/speciality distribution/public/documents/SURVEILLANCE/SVL Guides recommen
} 
What comes as a result of the comparison by CCBE of eleven Member States is indeed the different sources where national security is found as a concept. However, in spite of these differences in the legal instruments, a number of similarities can be drawn from this exercise.

Interestingly enough, domestic conceptualizations of national security include an explicit reference to the notion of sovereignty, territorial integrity and the protection of democratic $\operatorname{order}^{119}$ (for instance, this can be observed in the legal systems of Czech Republic ${ }^{120}$, France ${ }^{121}$, Greece ${ }^{122}$, Hungary ${ }^{123}$, Italy ${ }^{124}$ and the United Kingdom ${ }^{125}$ ). This confirms the point made above on the strict interconnection between sovereignty and national security, which, as we have been able to determine, is not only present in political theories, but finds its explications in both international laws and national statutes, too.

Furthermore, in many national frameworks, the results from the CCBE Study underline how other policy domains are also included under the realm of national security, such as, for instance the protection of a nation's citizens and residents against serious threats to their life, health and human rights as well as the conduct and promotion of a nation's foreign relations and commitment to the peaceful coexistence of nations. ${ }^{126}$ These domains, however, fall under the concept of public security in the EU secondary legislation as discussed in this section of this chapter. ${ }^{127}$ In this respect, two conclusions can be drawn; firstly, even though the definition of national security is not clearly defined in Member States' frameworks, national laws are nevertheless much less vague than EU law when it comes to delineating what competences fall under national security. Secondly, it appears that the EU concept of public security overlaps to an extent with the Member States notions of national security.

\section{Competent authorities under the DPLE Directive}

\subsection{General guidance}

Having established the uncertainty veiling the material scope of the DPLE Directive, we now turn our focus on the personal scope. As previously mentioned, the third condition for the applicability of the DPLE Directive is the concept of competent authorities, i.e. "any public authority competent for the prevention

dations/EN SVL 20190329 CCBE-Recommendations-on-the-protection-of-fundamental-rights-in-the-context-ofnational-security.pdf accessed 18 May 2019.

119 ibid, pp. 10, 11, 13, 14 and 18.

${ }^{120}$ Constitutional Act, art 1 (CZ).

121 Law L1111-1 Code of Defence (FR).

122 Law 2292/1995 (GR).

${ }^{123}$ National Security Services Act, Para. 74 (HU).

124 Law 124/2007, arts 6 and 7 (IT).

125 House of Lords, on the Secretary of State for the Home Department v Rehman [2001] UKHL 47.

${ }^{126}$ CCBE Recommendations on the protection of fundamental rights in the context of 'national security' (n 118), $p$ 18.

${ }^{127}$ See the concept of public security within secondary law regulating fundamental freedoms (in particular through the analysis by Panos Koutrakos n 71) and its definition within Regulation (EU) 2018/1807 (n 115). Similarly, public safety and health fall under the meaning of public security in the regime of the ECHR (see in particular Sofie StallaBourdillon n 50). 
[..] of criminal offences [..], including the safeguarding against and the prevention of threats to public security' or 'any other body or entity entrusted by Member State law to exercise public authority and public powers" for the same purposes. ${ }^{128}$ While the former may be understood as falling strictly within the field of criminal justice latter, the latter may potentially allow for a broader applicability of the DPLE Directive, as this concern was voiced by the EDPS ${ }^{129}$ and the WP29 ${ }^{130}$. In this respect, the body of recitals of the Directive provides a high-level form of guidance through a small set of examples.

More specifically, according to recital 11, "such competent authorities may include not only public authorities such as the judicial authorities, the police or other law-enforcement authorities but also any other body or entity entrusted by Member State law to exercise public authority and public powers for the purposes of this Directive. [..] For example, for the purposes of investigation detection or prosecution of criminal offences financial institutions retain certain personal data which are processed by them, and provide those personal data only to the competent national authorities in specific cases and in accordance with Member State law". The recital continues by pointing out that, in case where an authority also processes personal data for purposes other than the ones falling under the DPLE Directive, said authority would then be considered as a processor, pursuant to the DPLE Directive, of the personal data that the authority is bound to process on behalf of competent authorities. The authority in question, therefore, must abide by the DPLE Directive obligations for processors as regards its processing activities for the purpose of safeguarding public security, and the GDPR for its processing activities for other purposes.

Furthermore, recital 12 attempts to explain the sort of activities may fall under the concept of prevention of criminal offences, including the safeguarding against and prevention of threats to public security. In particular, "such activities can also include the exercise of authority by taking coercive measures such as police activities at demonstrations, major sporting events and riots. They also include maintaining law and order as a task conferred on the police or other law-enforcement authorities where necessary to safeguard against and prevent threats to public security and to fundamental interests of the society protected by law which may lead to a criminal offence". ${ }^{131}$

These recitals, nonetheless, do not draw a full and comprehensive picture. While some authorities, like law enforcement agencies or bank institutions when performing their tasks under anti-money laundering obligations ${ }^{132}$, will clearly fall under the scope of the Directive, others, like ones entrusted for instance with the management of Critical Infrastructures (hereinafter $\mathrm{Cl}$ ), could fall between the cracks. $\mathrm{Cl}$

\footnotetext{
128 (n 13).

${ }^{129} \operatorname{EDPS}(\mathrm{n} 5)$.

${ }^{130}$ Article 29 Working Party (n 6).

131 The recital further states that 'Member States may entrust competent authorities with other tasks which are not necessarily carried out for the purposes of the prevention, investigation, detection or prosecution of criminal offences, including the safeguarding against and the prevention of threats to public security, so that the processing of personal data for those other purposes, in so far as it is within the scope of Union law, falls within the scope of Regulation (EU) 2016/679'.

132 See for instance the obligations under EU and national law: https://ec.europa.eu/info/policies/justice-andfundamental-rights/criminal-justice/anti-money-laundering-and-counter-terrorist-

financing en\#eulegalframeworkonamlctf accessed 19 May 2019.
} 
authorities are entrusted with the power to secure their facilities by national, European and international legal instruments. ${ }^{133}$ In particular, according to the legal frameworks in question, $\mathrm{Cl}$ authorities are under the obligation to prevent physical threats and attacks against their infrastructures or individuals on field, attacks which comprise of criminal offences in the realm of criminal laws, as well as a wide range of attacks attempted or committed against their information systems, which also constitute a criminal act and as such will have to be investigated and prosecuted ${ }^{134}$. Finally, as these instruments do not define these powers and authorities as public, it is up to the Member States to decide. Through the example of $\mathrm{Cl}$ authorities, it is sought to demonstrate how further examination of the national regulation on such entities and on the DPLE Directive should be taken into account in order to clarify the ambiguity of whether such authorities may be considered as a 'public authority' or 'other body with public authority and public powers' within the meaning of the DPLE Directive.

Against this backdrop, we explore the national laws of six Member States, i.e. the United Kingdom, Republic of Ireland, Italy, Belgium, Germany and France implementing the DPLE Directive, and their understanding of the scope of the directive and the concept of a competent authority.

\subsection{National implementation}

\section{United Kingdom}

The UK 2018 Data Protection Act (hereinafter, the Act) ${ }^{135}$, which received the Royal Assent in May 2018, has been one of the first national laws in Europe to provide a full implementation of the whole EU privacy reform package, hence comprising both GDPR and DPLE Directive. ${ }^{136} \mathrm{~A}$ third framework complements the first two, one which makes reference to the Council of Europe's Convention 108: it is the case of the data protection regime in the national security domain. Prominently, the United Kingdom therefore offers one of the most comprehensive legislations, including in the same act (but strictly separated in terms of provisions and obligations) ordinary regime (GDPR), law enforcement regime (LED), and national security regime (Convention 108), mitigating the risk of legal uncertainty and fragmentation.

With regard to national security, the Act is structured as follows: within the GDPR implementation (Part2, Chapter 3), national security is considered as an exemption to the general GDPR application, alongside

\footnotetext{
133 See inter alia Council Directive 2008/114/EC of 8 December 2008 on the identification and designation of European critical infrastructures and the assessment of the need to improve their protection, OJ L 345, 23.12.2008, 75; Directive 2013/40/EU of the European Parliament and of the Council of 12 August 2013 on attacks against information systems and replacing Council Framework Decision 2005/222/JHA, OJ L 218, 14.8.2013, 8, rec.4; Directive (EU) 2016/1148 of the European Parliament and of the Council of 6 July 2016 concerning measures for a high common level of security of network and information systems across the Union, OJ L 194, 19.7.2016, 30.

${ }^{134}$ Council of Europe, Convention on Cybercrime, 23.11.2001, European Treaty Series No 185; Directive 2013/40/EU of the European Parliament and of the Council of 12 August 2013 on attacks against information systems and replacing Council Framework Decision 2005/222/JHA [2013] OJ L 218, 8; Council of Europe, Convention on Cybercrime, 23.11.2001, European Treaty Series No 185.

135 Data Protection Act 2018, c 12 (UK) (Data Protection Act 2018).

136 It is to be noted, for the sake of completeness, that the Data Protection Act does not only cover the implementation of these laws.
} 
data processing for defence purposes. Furthermore, in Part 4, the Act lays down a proper set of provisions which do not use the wording 'national security' anymore, replaced by the narrower definition 'Intelligence Services Processing' ${ }^{137}$.

In addition, according to the implementation of the DPLE Directive within the Act, competent authorities are those with the statutory functions of public authority or law enforcement; From a mere public-sector perspective, the competent authorities falling under this definition are explicitly enlisted in Schedule 7 (Section 30) of the Act, which provides a long series of governmental bodies that meet the requirements of the DPLE Directive. It should be noted that such a list, might actually be amended at any time by the Secretary of State, who has got the power (by law) of adding or removing public bodies from it. Coming back to the general definition by the Act, according to the British Data Protection Authority the Information Commissioner's Office (hereinafter ICO), the wording 'competent authority' translates into "any public authority with powers to investigate and/or prosecute crimes and impose sentences; or any other organizations (such as a private company/contractor) empowered by law [..] to exercise those powers in a way that gives them control over the data i.e. as a data controller, as opposed to a data processor". ${ }^{138}$

As a consequence, competent authorities falling under the DPLE Directive for the British legislator are both public agencies and private ones, as long as the latter category has the status of a data controller (ergo: competent authorities cannot be private organizations acting in a data processing chain as data processors). Therefore, under such a provision, companies entrusted to undertake public functions in the criminal justice sector (for instance, organizations involved in the correctional system), will be considered competent authorities when meeting two conditions: being data controller and being empowered by a statutory law, which means that simple contractual arrangements might not be sufficient to fulfil this requirement. Conversely, if a private organization is asked to transfer data to a police agency for criminal investigation purposes, that same organization will still have to adhere to the GDPR: personal data will fall under the DPLE Directive regime only when they will be transferred to the law enforcement authority. ${ }^{139}$

\section{Republic of Ireland}

Similarly, the Republic of Ireland has included provisions on personal data processing for law enforcement purposes within a piece of legislation which comprises a number of general data protection principles deriving from the GDPR. The 2018 Irish Data Protection Act (hereinafter, the 'Irish Act'), dedicates its

\footnotetext{
${ }^{137}$ According to the common security governance of the United Kingdom and the commentary of the British Regulator, the Information Commissioner's Office, intelligence services (entrusted of protecting national security) are MI5, MI6 and GCHQ.

138 Information Commissioner's Office, Guide to Law Enforcement Provisions, (2017), v.1.0.6 'Law Enforcement Directive | Data Protection Commission' (Law Enforcement Directive / Data Protection Commission) <https://www.dataprotection.ie/organisations/law-enforcement-directive> accessed 13 May 2019.

139 This is the case of financial institutions, for instance, processing personal data for anti-fraud or anti-money laundering finalities: in these circumstances, data will follow the ordinary GDPR regime of the Act until they are transferred to the police authority requesting it.
} 
entire Part 5, constituted by six Chapters), to the implementation of the DPLE Directive in the national legal framework. ${ }^{140}$ The legal regime outlined in Part 5 therefore applies when two conditions are met. Firstly, the data processing operation is carried out for law enforcement purposes, intended by article 70 as prevention, investigation, detection, prosecution and execution of criminal offences, unless the processing of data is undertaken either for the purposes of safeguarding national security, defence or foreign state relations, or under the 2014 Criminal Justice Act on Forensic Evidence and DNA Database System or under the 2018 Automated Vehicle registration Searching Act. In this latter case, the 1988 Irish Data Protection Act will still apply and thus not be repealed by the 2018 Irish Act (Part 1, article 8). The second condition to be met is indeed that the organization carrying out the data processing must fall under the definition of competent authority.

In the Irish context, competent law enforcement authorities would naturally be the An Garda Síochána, although the definition extends to other organizations, as enshrined in the wording of the DPLE Directive. Differently from the British Act, the Irish one does not provide for an explicit list of competent authorities. Specifically, the Irish Act deliberately allows for a larger number of public organizations to fit in this definition. To prove the broadness of this wording, the Irish Data protection Commission (An Coimisinéir Cosanta Sonrai) makes the example of local authorities or public transport companies processing fines and sanctions, concluding that it is impossible to delineate exactly the contours of public competent authorities, and that therefore this will have to be done on a case-by-case basis ${ }^{141}$.

Furthermore, private organizations may fit, under the fulfilment of a number of requirements, within the definition of competent authorities, as dictated by the DPLE Directive definition of 'any other body or entity'. ${ }^{142}$ As a consequence, any private organization undertaking law enforcement activities must be entrusted by a legislation to do so, in order to be considered authority. Lastly, competent authorities must be data controllers. In the definition of data processors, in fact, the wording results to be broader, hence including any natural or legal person, public agency or other body. ${ }^{143}$

Italy ${ }^{144}$

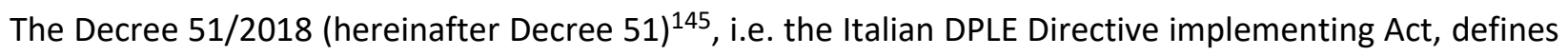
its material scope of application as "automated or semi-automated personal data processing of natural persons by competent authorities for the purposes of prevention, investigation, detection and prosecution

\footnotetext{
140 Data Protection Act 2018 - No. 7 of 2018.

141 'Law Enforcement Directive | Data Protection Commission' (n 138).

142 Data Protection Act 2018 - No. 7 of 2018 art 69.

143 ibid.

${ }^{144}$ All translations are the author's, unless otherwise indicated.

${ }^{145}$ For more information, see 'Approvato II Decreto Di Attuazione Della Direttiva UE in Materia Di Trattamento Dei Dati Personali Da Parte Delle Autorità Competenti - ROSSI, COPPARONI \& PARTNERS' <http://www.rpcstudiolegale.it/2018/06/08/approvato-il-decreto-di-attuazione-della-direttiva-ue-in-materia-ditrattamento-dei-dati-personali-da-parte-delle-autorita-competenti/> accessed 10 May 2019.
} 
of criminal offences and the execution of criminal sanctions". ${ }^{146}$ The above data processing includes, inter alia, the processing for archiving purposes or the processing of the same data in a 'police database'. It should be noted that, according to some authors, the Italian legislator has exercised the flexibility clause of article 45 of the DPLE Directive, deliberately leaving out from the supervision of the Italian Data protection Authority (Garante per la Protezione dei Dati Personali) the processing of personal data by the judiciary body when exercising its decisional activities, in order to respect the principle of judiciary independence. ${ }^{147}$ In the same article, while the legislator specifies that the data processing operation undertaken for public security purposes falls within the scope of application of the Decree 51, national security is nevertheless explicated as an out-of-scope domain. ${ }^{148}$

With regard to public sector competent authorities, it is interesting to note that the Italian legislator made explicit that competent authorities are any public bodies undertaking law enforcement tasks, be it Italian, European or third-country ones. ${ }^{149}$ In its opinion $86 / 2017^{150}$, issued during the drafting phase of the Decree 51, the Italian Garante explored this topic with regard to Italian public agencies, making an important series of operative distinctions within the term competent authority. For instance, the Garante's opinion states that the Decree should not be applicable a priori to all public authorities' data processing with a link of any sort with police activities (for instance, in the case of data processing operations undertaken by Prefectures, Custom Agencies or local Police): in such cases in fact, the DPLE Directive will only apply insofar as the processing demonstrates a clear and strict link with the enforcement of a criminal provision.

The competent authorities which are not public bodies are further defined as "any other entity or organization tasked by the national legal system with law enforcement activities". ${ }^{151}$ While the translation of this wording may not look particularly problematic, the Italian wording opens up for a broad interpretation of the term 'national legal system' (tr. ordinamenti interni), as it does not specify in narrow terms what sort of national law would suffice (would it be a Law, a Law Decree, a Legislative Decree?). Contextually, the wording seems to leave room for foreign organizations too, since "as tasked by the

\footnotetext{
${ }^{146}$ Decree 51/2018, art 1 (IT) (Decree 51/2018).

${ }^{147}$ See for instance, Monica A. Senor, 'Una Overview Sulla Data Protection in Ambito Di Polizia e Giustizia Penale ICT Security Magazine' <https://www.ictsecuritymagazine.com/articoli/una-overview-sulla-data-protection-inambito-di-polizia-e-giustizia-penale/> accessed 10 May 2019.

${ }^{148}$ According to the statutory Law No. 124 from 2007 [Sistema di Informazione per la Sicurezza della Repubblica e Nuova Disciplina del Segreto (tr., Intelligence System for the Republic's Security and New State Secret Framework)], these bodies result to be the DIS - Department for Information and Security (the general intelligence directorate), the Agency for Internal Information and Security - AISI (the internal security services) and the Agency for External Information and Security - AISE (the foreign intelligence agency).

149 Decree 51/2018, art 2(g).

150 Italian DPA, art 1, Capo 5.1, Registro dei provvedimenti n. 86 del 2 marzo 2017 'Parere Su Uno Schema Di d.P.R. Ai Sensi Dell'art 57 Del Codice, in Tema... - Garante Privacy' <https://www.garanteprivacy.it/web/guest/home/docweb/-/docweb-display/docweb/6197365> accessed 10 May 2019.

${ }^{151}$ Decree 51/2018, art 2(g).
} 
national legal system" could refer, interpreted broadly, to private organizations entrusted by foreign countries to undertake law enforcement tasks in those same countries. Lastly, and similarly to the British and Irish frameworks, the Decree 51 specifies what established organizations can undertake the functions of controllers and processors: competent authorities are only controllers ${ }^{152}$, while processor tasks can be contracted to any legal or natural persons ${ }^{153}$.

Belgium $^{154}$

Alike the United Kingdom, Belgium also regulates in one law the processing of personal data by all entities, whether they fall within the scope of the GDPR (Title 1) or the DPLE Directive (Title 2), or outside the scope of both instruments (Title 3). ${ }^{155}$ It should first be noted that national security is not mentioned explicitly as falling outside the scope. Furthermore, Belgium repeats in its national law verbatim the relative provision regarding the scope of the DPLE Directive (article 27). Interestingly enough, it provides for a detailed definition of a competent authority within the meaning of the DPLE Directive through a seemingly exhaustive list of entities (article 26.7). The additional particularity observed is that competent authorities also entail units within intelligence services. More specifically, the list of competent authorities includes inter alia the General Administration of Customs and Excise, the Passenger Information Unit, the Financial Information Processing Unit and the Investigation Service of the Standing Committee for the Control of Intelligence Services in the framework of it judicial missions.

According to the Belgian approach, then, an extensive part of rules and derogations specific to entities that to be regulated separately, follows the provisions implementing the GDPR and the DPLE Directive in the law. ${ }^{156}$ The Belgian Data Protection Authority explain it its opinion that these entities fall outside the scope of the two legal instruments due to their link to national security. ${ }^{157}$ This approach seems not to allow for a broadening of scope of the DPLE Directive rules to authorities other than the ones explicitly named in the Belgian law.

France $^{158}$

French law, in a rather complicated manner, excludes state security, defence and public security from the scope of application, unless otherwise prescribed by the chapter within the law transposing the DPLE

\footnotetext{
152 Decree 51, art 2(h).

153 Decree 51, art 2(h).

154 All translations are the author's, unless otherwise indicated.

155 Loi du 30 juillet 2018 relative à la protection des personnes physiques à l'égard des traitements de données à caractère personnel / Wet betreffende de bescherming van natuurlijke personen met betrekking tot de verwerking van persoonsgegevens, Moniteur Belge / Belgish Staatsblad, 05-09-2018.

156 Intelligence and security services other than the ones that fall within the definition of competent authorities, Armed Forces, in the context of classification and security clearings, safety certificates and safety advice, the coordination body for the threat analysis and the Passenger Information Unit.

157 Autorité de protection des données - APD / Gegevensbeschermingsautoriteit - GBA (Belgian DPA), Avis $n^{\circ}$ 33/2018 du 11 avril 2018 / Advies nr. 33/2018 van 11 april 2018.

${ }^{158}$ All translations are the author's, unless otherwise indicated.
} 
Directive. ${ }^{159}$ The chapter in question, nonetheless, refers to the DPLE Directive purpose of protection against threats to public security and the prevention of such threats (article 70). Moreover, it provides for the same definition of competent authorities as the DPLE Directive, in a way that resembles a mere translation of the relevant provision.

The French data protection authority, Commission Nationale de l'Informatique et des Libertés (hereinafter CNIL) recently provided for an explanatory text as regards the transposition of the DPLE Directive. ${ }^{160}$ Apart from law enforcement and judicial authorities, according to CNIL, the internal services of safety of $\mathrm{Cl}$ authorities such as the Autonomous Operator of Parisian Transports (Régie Autonome des Transports Parisiens - RATP) and the French National Railway Company (Société nationale des chemins de fer français - SNCF), and the approved sports federations for the purpose of securing sports events consist of competent authorities. The examples provided by CNIL seem to confirm the hypothesis that competent authorities may encompass a wide range of authorities entrusted with security in the broad sense.

\section{Germany}

The German Federal Data Protection Act (hereinafter the Federal Act) defines controllers within the meaning of the DPLE Directive as public bodies competent for the prevention, investigation, detection or prosecution of criminal or administrative offences or the execution of criminal or administrative penalties, as far as they process data for the purpose of carrying out these tasks (Part 3). ${ }^{161}$ It further clarifies that the prevention of criminal offences includes the protection against and prevention of threats to public security. The provisions transposing the DPLE Directive rules are also applicable vis-à-vis public bodies responsible for executing penalties, criminal measures, and educational or disciplinary measures as referred to in the Juvenile Court Act. Moreover, the Federal Act regulates processing activities that fall outside the scope of both GDPR and DPLE Directive (Part 4). ${ }^{162}$

What is interesting and exceptional about the Federal Act is that it includes entities entrusted with public security under the scope of the GDPR (Part 1). More specifically, the GDPR applies to a broad range of public and private bodies of the Federation and of the Länder. The processing of sensitive personal data by public bodies is permitted when it is "urgently necessary for reasons of substantial public interest"; "necessary to prevent a substantial threat to public security"; is "urgently necessary to prevent substantial harm to the common good or to safeguard substantial concerns of the common good"; or "necessary for

159 LOI n²018-493 du 20 Juin 2018 relative à la protection des données personnelles, Journal Officiel de la République Française (JORF), 21-06-2018, Chapitre XIII (FR).

${ }^{160}$ Commission Nationale de I'Informatique et des Libertés - CNIL, 'Directive " Police-Justice » : de quoi parle-t-on?', 20 February 2019, https://www.cnil.fr/fr/directive-police-justice-de-quoi-parle-t accessed 19 May 2019.

${ }^{161}$ Gesetz zur Anpassung des Datenschutzrechts an die Verordnung (EU) 2016/679 und zur Umsetzung der Richtlinie (EU) 2016/680 (Datenschutz-Anpassungs- und -Umsetzungsgesetz EU - DSAnpUG-EU), Bundesdatenschutzgesetz vom 30. Juni 2017 (BGBI. I S. 2097), as translated by the Language Service of the Federal Ministry of the Interior.

162 In particular, the law states that the transfer of personal data to a third country, to supranational or intergovernmental bodies or to international organizations in the context of activities outside the scope of GDPR and DPLE Directive shall be permitted in addition to the cases permitted under the GDPR, also when the processing is necessary to perform tasks for urgent reasons of defence or to fulfil supra- or intergovernmental obligations of a public body of the Federation in the field of crisis management or conflict prevention or for humanitarian measures. 
urgent reasons of defence or to fulfil supra- or intergovernmental obligations of a public body of the Federation in the field of crisis management or conflict prevention or for humanitarian measures". The German law is innovative also in the sense of introducing this notion of 'urgent necessity'.

Finally, the processing activities of personal data in the context of video surveillance activities of publicly accessible spaces also fall under the GDPR. In particular, the Federal Act states that "for video surveillance of large publicly accessible facilities, such as sport facilities, places of gathering and entertainment, shopping centres and car parks, or vehicles and large publicly accessible facilities of public rail, ship or bus transport", the protection of the lives, health and freedom of persons present is regarded as a very important interest and hence as the legal basis for such processing activities (Chapter 2, section 4). According to German law, contrary to the national laws analysed above, a broad range of entities entrusted with public security, including for example $\mathrm{Cl}$ authorities, have to abide by the GDPR and not the DPLE Directive.

\section{Conclusions}

Based on the three-layered examination of the scope of the DPLE Directive, a number of conclusions can be drawn. Starting with the first layer, the analysis of the sources under general theories of international law reveals the lack of effort by scholars and law-makers in defining national security. However, some recurring elements have been usefully pointed out in order to understand the contextualization of such a terminology. For example, the historical dependence of national security as an embodiment of the sovereignty principle is a trend that we encounter in political science, security studies, international treaties and even national laws. It is a building block of national security doctrine to refer to sovereignty and its exercise, seen as the explication of a social contract between the citizens and the executive, a relationship which calls for reciprocal acceptance, democratic accountability and control.

All sources in fact reveal, in different forms and fashions, that invocation of national security reasons is conditioned to the recurrence of exceptional conditions. As such, most of the treaties (even those including a self-judging clause), either circumscribe narrowly the national security exception (often considering it as a separate concept from the notions of 'public order', 'public safety', 'public security' or 'crime prevention'), or foresee a judicial scrutiny on the invocation of national security by states, often substantiated in a judicial evaluation of appropriateness, necessity, proportionality and legality.

In the second layer of the EU regime, while Union law refers to national security in order to delineate its competences and regulatory powers, it also refrains from providing a definition. The term seems to be understood as linked to the core, sovereignty and democratic nature of a state, in a similar way as analysed under general theories and international law. The concept of public security under EU law may also be invoked by Member States in order to repress the applicability of EU law. At the same time, it serves as one of EU's highest priorities; public security of EU citizens increasingly gives rise to EU policy and legislation, with counter-terrorism often as its center-line. Public security, however, evolves through secondary legislation, as the latter is informed by the jurisprudence of the ECJ, into an autonomous 
concept. This concept appears expansive and inclusive of domains that under international or national law would have been considered to constitute national security.

Therefore, the paradox observed is that public security, when invoked as a derogation, may be as broad as to overlap with national security, even though it is still subject to judicial scrutiny and must be interpreted narrowly. The question then arises vis-à-vis the effects of this broadening of the term of public security, when it is established as the rule and no longer as an exception, for instance in the case of the DPLE Directive. It could be inferred that public security might continue to be as broad as consisting of both the internal and external security of a Member State, public safety, societal security, survival of the population and peaceful coexistence of states. One may then consider in the scope of public security all those bodies and entities tasked not only with the identification and criminalisation of a threat (strictly speaking, law enforcement authorities), but also organisations competent or tasked with the prevention and the minimisation of a broader range of security risks. As a consequence, it will then be up to Member States to name their exceptions under a more restricted notion of national security.

Finally according to the analysis under the third layer, the distinction between data protection frameworks, i.e. GDPR, DPLE Directive or other, boils down to the level of strictness of rules. Contrary to the GDPR, the DPLE Directive is more flexible from a data controller's perspective, allowing for a more restricted exercise of data subject rights. Nonetheless, as observed in this chapter, several Member States (e.g. United Kingdom, Belgium and Germany) have opted for a granular regulatory approach affecting a wide range of authorities.

To conclude, on the grounds of national security, intelligence services seem to fall outside the scope of the GDPR and the DPLE Directive, while they may still be subject to some form of regulation. As regards the regulatory discretion states enjoy, international bodies, such as the UN, advocate more accountable and transparent intelligence oversight. Insofar as the concept of public security is concerned, it becomes expansive under EU law while it lacks clarity within the DPLE Directive. Brought together, these elements allow for various authorities entrusted by Member States with the public mandate to ensure internal and external security, inter alia critical infrastructures authorities as aforementioned, to be considered as competent authorities. In such case, they will have to comply with the DPLE Directive as opposed to the GDPR, in relation to their activities within this context. In practice, that may be a very fine line to draw.

Acknowledgement The research for this chapter has been performed and has been partially funded by the project InfraStress (GA 833088) under the Horizon 2020 scheme of the European Commission and call SU-INFRA01-2018-2019-2020 and partially by the project SAURON (GA 740477) under the Horizon 2020 scheme of the European Commission and call CIP-01-2016-2017.

\section{Bibliography}

'Approvato II Decreto Di Attuazione Della Direttiva UE in Materia Di Trattamento Dei Dati Personali Da Parte Delle Autorità Competenti - ROSSI, COPPARONI \& PARTNERS' 
http://www.rpcstudiolegale.it/2018/06/08/approvato-il-decreto-di-attuazione-della-direttiva-ue-inmateria-di-trattamento-dei-dati-personali-da-parte-delle-autorita-competenti/

Article 29 Data Protection Working Party, Opinion 03/2015 on the draft directive on the protection of individuals with regard to the processing of personal data by competent authorities for the purposes of prevention, investigation, detection or prosecution of criminal offences or the execution of criminal penalties, and the free movement of such data, WP233, 01 December 2015

Autorité de protection des données - APD / Gegevensbeschermingsautoriteit - GBA, Avis n³3/2018 du 11 avril 2018 / Advies nr. 33/2018 van 11 april 2018

Azoulai L and Coutts S, (2013) 'Restricting Union citizens' residence rights on grounds of public security. Where Union citizenship and the AFSJ meet: P.I.' Common Market Law Review, 50(2), 553

Besson, S 'Sovereignty' <https://opil.ouplaw.com/view/10.1093/law:epil/9780199231690/law9780199231690-e1472>

Bigo D (1994), 'The European internal security field: stakes and rivalries in a newly developing area of police intervention', in M. Anderson and M. den Boer (eds), Policing Across National Boundaries (London: Pinter), 161

Blockmans S, What Comes after the Last Chance Commission? Policy Priorities for 2019-2024. (Centre for European Policy Studies 2019)

Boehm F, 'Data Processing and Law Enforcement Access to Information Systems at EU Level' (2012) 36 Datenschutz und Datensicherheit - DuD 339

Brown H, 'U.S. National Security: The Next 50 Years', (2000), Paul H. Nitze Award Lecture, Center for Naval Analyses

Buzan B, 'Peace, Power, and Security: Contending Concepts in the Study of International Relations' (1984) 21 Journal of Peace Research 109

Cameron I, 'National Security and the European Convention on Human Rights', (Kluwer Law International 2000)

CCBE Recommendations on the protection of fundamental rights in the context of 'national security' (2019)

https://www.ccbe.eu/fileadmin/speciality distribution/public/documents/SURVEILLANCE/SVL Guides $r$ ecommendations/EN SVL 20190329 CCBE-Recommendations-on-the-protection-of-fundamentalrights-in-the-context-of-national-security.pdf

Claes M, 'The Primacy of EU Law in European and National Law' [2015] The Oxford Handbook of European Union

<http://www.oxfordhandbooks.com/view/10.1093/oxfordhb/9780199672646.001.0001/oxfordhb9780199672646-e-8> accessed 5 April 2019

Claes M, 'National Identity: Trump Card or Up for Negotiation?' in Alejandro Saiz Arnaiz and Carina Alcoberro Llivina, National Constitutional Identity and European Integration (2013), Intersentia 109-140 
De Hert P and Papakonstantinou V, 'The Police and Criminal Justice Data Protection Directive: Comment and Analysis' (2012) New Journal of European Criminal Law, 7(1), 7

Dimitrova A and Brkan M, (2017) 'Balancing National Security and Data Protection: The Role of EU and US Policy-Makers and Courts before and after the NSA Affair', Journal of Common Market Studies, 751

Dobbs M, (2014) 'Sovereignty, article 4(2) TEU and the respect of national identities: Swinging the balance of power in favour of the member states?', Yearbook of European Law, 33(1), 298

Eisenhut D, 'Sovereignty, National Security and International Treaty Law. The Standard of Review of International Courts and Tribunals with Regard to "Security Exceptions"' (2010) 48 Archiv des Völkerrechts 431

European Data Protection Supervisor, Opinion 6/2015, 28 October 2015, p. 6

Finnis J, 'Absolute Rights: Some Problems Illustrated' (2016) 61 American Journal of Jurisprudence 195

Gray C, 'A Crisis of Legitimacy for the UN Collective Security System?' (2007) 56 The International and Comparative Law Quarterly 157

Guastaferro B, 'Beyond the Exceptionalism of Constitutional Conflicts: The Ordinary Functions of the Identity Clause' (2012) Yearbook of European Law 263-318

Hahn MJ, 'Vital Interests and the Law of GATT: An Analysis of GATT's Security Exception' (1991) 12 Michigan Journal of International Law 558

Hobbes T, Leviathan-Or the Matter, Form and Power of a Common-Wealth Ecclesiastical and Civil (1651) ed. by I Shapiro (New Haven, CT: Yale University Press, 2010)

Human Rights Council, Report of the Special Rapporteur on the right to privacy (2019), A/HRC/40/63

Human Rights Council, 25/117 Panel on the right to privacy in the digital age (2014) A/HRC/25/117

Information Commissioner's Office, Guide to Law Enforcement Provisions, (2017), v.1.0.6 'Law Enforcement Directive | Data Protection Commission' (Law Enforcement Directive | Data Protection Commission) <https://www.dataprotection.ie/organisations/law-enforcement-directive>

Knorr K, 'National Security Studies: Scope and Structure of the Field', in Frank N. Trager and PhilipS. Kronenberg (eds.), National Security and American Society: Theory, Process and Policy (Lawrence, KS, 1973)

Koutrakos P, (2016) 'Public Security Exceptions and EU Freed Movement Law', in P. Koutrakos, N. Nic Shuibhne \& P. Syrpis (Eds.) Exceptions from EU Free Movement Law: Derogation, Justification and Proportionality (Modern Studies in European Law), Oxford: Hart Publishing

Kuner $\mathrm{C}$ and others, 'An Unstoppable Force and an Immoveable Object? EU Data Protection Law and National Security' 3

Macken C, 'Preventive Detention and the Right of Personal Liberty and Security under the International Covenant on Civil and Political Rights, 1966' (2005) 26 Adelaide Law Review 1 
Marquenie T, 'The Police and Criminal Justice Authorities Directive: Data protection standards and impact on the legal framework' (2017) Computer Law \& Security Review, 33:3, 324

Midelieva L, 'The Elusive Cause and the Extensive Effect of the Principle of Supremacy of EU Law' (2017) 7 Southampton Student Law Review 21

Mijalkovic S and Blagojevic D, 'The Basis of National Security in International Law' [2014] Nauka, bezbednost, policija 49

Murrill BJ, 'The "National Security Exception" and the World Trade Organization' 5

'OHCHR | States Must Bridge Privacy Gap in Intelligence Sharing, Says UN Human Rights Expert' <https://www.ohchr.org/EN/NewsEvents/Pages/DisplayNews.aspx?NewsID=24242\&LangID=E>

Quintel T, 'European Union - Article 29 Data Protection Working Party Opinion on the Law Enforcement Directive' (2018) 4 European Data Protection Law Review 104

Rose-Ackerman S and Billa B, 'Treaties and National Security' (2018), reprinted in Yale Law School Faculty Scholarship Series, Paper 5954061.

Romm J J, 'Defining National Security: The Nonmilitary Aspects' (1993), Council on Foreign Relations Press 'Securitization - International Relations - Oxford Bibliographies' <https://www.oxfordbibliographies.com/view/document/obo-9780199743292/obo-97801997432920091.xml>

Senor M A, 'Una Overview Sulla Data Protection in Ambito Di Polizia e Giustizia Penale - ICT Security Magazine' <https://www.ictsecuritymagazine.com/articoli/una-overview-sulla-data-protection-inambito-di-polizia-e-giustizia-penale/>

Sliwinski KF, 'Moving beyond the European Union's Weakness as a Cyber-Security Agent' (2014) 35 Contemporary Security Policy 468

Stalla-Bourdillon S, 'Privacy Versus Security ... Are We Done Yet?', in Sophie Stalla-Bourdillon, Joshua Phillips, Mark D. Ryan (eds), 'Privacy vs. Security' (Springer London, Springer Briefs in Cybersecurity 2014), Van den Berg B and Prins R, 'A Multi-Actor Perspective on Security and Safety - Perspectives and Levels' (Coursera) <https://www.coursera.org/lecture/security-safety-globalized-world/a-multi-actorperspective-on-security-and-safety-duiLA> accessed 13 May 2019

UN Sub-Commission on Prevention of Discrimination and Protection of Minorities, Siracusa Principles on the Limitation and Derogation of Provisions in the International Covenant on Civil and Political Rights Annex, UN Doc E/ CN.4/1984/4 (1984), as reported in CCBE Recommendations on the protection of fundamental rights in the context of 'national security' - 2019

Weatherill S, 'Distinctive Identity Claims, Article 4(2) TEU (and a Fleetingly Sad Nod to Brexit) Editorial Note' (2016) 12 Croatian Yearbook of European Law and Policy VII

'Wyatt and Dashwood's European Union Law: Alan Dashwood: Hart Publishing' <https://www.bloomsbury.com/in/wyatt-and-dashwoods-european-union-law-9781847317667/> 